\title{
Water Governance in Mediterranean Farming Systems through the Social-Ecological Systems Framework-An Empirical Case in Southern Portugal
}

\author{
Taiana Homobono $^{1, *(\mathbb{D})}$, Maria Helena Guimarães ${ }^{1}(\mathbb{D})$, Catarina Esgalhado ${ }^{1}\left(\mathbb{D}\right.$ and Lívia Madureira ${ }^{2}$
}

1 MED—Mediterranean Institute for Agriculture, Environment and Development, Universidade de Évora, Polo da Mitra, Ap. 94, 7002-554 Évora, Portugal; mhguimaraes@uevora.pt (M.H.G.); cesg@uevora.pt (C.E.)

2 Centre for Transdisciplinary Development Studies (CETRAD), Universidade Trás-os-Montes e Alto Douro (UTAD), Quinta de Prados, 5000-554 Vila Real, Portugal; 1madurei@utad.pt

* Correspondence: taihomobono@gmail.com

check for updates

Citation: Homobono, T.; Guimarães, M.H.; Esgalhado, C.; Madureira, L. Water Governance in Mediterranean Farming Systems through the Social-Ecological Systems Framework-An Empirical Case in Southern Portugal. Land 2022, 11, 178. https://doi.org/10.3390/land 11020178

Academic Editors: Carla Rolo Antunes and Nir Krakauer

Received: 10 December 2021

Accepted: 20 January 2022

Published: 23 January 2022

Publisher's Note: MDPI stays neutral with regard to jurisdictional claims in published maps and institutional affiliations.

Copyright: (C) 2022 by the authors. Licensee MDPI, Basel, Switzerland. This article is an open access article distributed under the terms and conditions of the Creative Commons Attribution (CC BY) license (https:// creativecommons.org/licenses/by/ $4.0 /)$.

\begin{abstract}
Water governance is a major challenge in the Mediterranean context. Any action to drive water governance towards sustainability needs to be grounded in a holistic understanding of such challenges. Therefore, a first step towards the improvement of water governance is a grounded understanding of what is at stake, who are the actors involved, and how they interact. To achieve this level of understanding, we propose the use of the social-ecological Systems (SES) framework. This framework was developed to grasp the complexity of issues related to the sustainable use of public goods such as water. This study looks at water governance in the farming sector of three municipalities in the Alentejo and Algarve, in the south of Portugal. Data were collected using a literature review and 22 semi-structured interviews with territorial actors (i.e., public administration, non-governmental associations, private sector, decision-makers, and farmers). By using the SES framework, we provide an integrated characterization of water governance in the case study and identify the implicated factors. Between these factors, and focusing on the overlap between literature and actors' perspectives, are (1) the lack of integrated and supported strategies for development, and (2) lack of communication between the actors that need to congregate efforts towards sustainable use of water resources. The study found few examples of collective efforts and long-lasting networks of collaboration, especially between science and practice. We conclude by arguing that place-based tailored policies are needed. Such policies should promote communication and collective actions between researchers, local organizations, public administration, and farmers.
\end{abstract}

Keywords: SES framework; water governance; farming systems; Mediterranean; local dynamics

\section{Introduction}

Management of natural resources requires coordination and guidance for human uses of such resources, as well as an integration of their impacts on the environment [1,2]. Governance models are understood as the routine within an institutional setting in which decisions are made and implemented and their effects addressed [3]. As such, governance models incorporate accepted and historically repeated ways of facing and finding solutions to societal challenges and illuminate the practical administrative organization of social relations and stakes [4]. Accordingly, governance models are contextual mixtures of particular ways of viewing the world, policy goals, tools for implementation, policies, and specific management solutions applied at a given place and time through locally embedded practices of actors.

Water is a common pool resource, i.e., it is finite, yet its characteristics make it costly, although not impossible, to exclude potential beneficiaries from obtaining benefits from its use [5], which offers unique challenges for its management. As such, water governance towards sustainability implies overcoming conflicting policy issues and finding consensus 
between the interests of the different parties involved within the thresholds established by ecosystems, and encouraging the use of participatory methods in decision-making processes [6]. Despite the importance of actors' involvement in water governance, to the best of our knowledge, no framework links the different dimensions of relationships between all user types $[7,8]$.

Water is fundamental for human well-being and is related to all economic activities, particularly agriculture $[9,10]$. Population growth and increasing food demand are pushing for higher water consumption [8]. At the same time, expected climate changes are also likely to decrease water availability [11], further aggravated by land degradation [12,13]. The growing pressure on freshwater resources negatively impacts not only food production, but also health security and ecological functioning, biodiversity, and the resilience of terrestrial and aquatic systems [14,15]. Addressing the increasing concerns about water scarcity and its consequences entail research and policy efforts towards sustainable solutions for its governance that can balance food production, water availability and quality, and ecosystem services provisioning.

The Mediterranean region is characterized by a semi-arid climate, high variability of rainfall, and susceptibility to drought [16]. Further, climate scenarios point to trends in longer and more severe soil water deficits and higher air and soil temperatures [17]. Despite the legacy of well-adapted farming systems, climate change scenarios, together with a pressure to meet production goals, sparked a debate on the role of water and irrigation in Mediterranean agriculture [18-20].

To grasp the complexity of water governance issues related to farming, we need to compile and integrate different sources of knowledge. Therefore, tools that are systemic and that allow a holistic contextualization of a real-world problem can be useful. Therefore, the concept of social-ecological systems is useful while dealing with water governance challenges since it immediately signals that such a topic is both a social and ecological issue and that the focus should be on interactions [21-23]. Several tools and frameworks have been developed to arrive at this level of characterization of a sustainability problem [24]. In the present study, we opted to use the social-ecological systems (SES) framework first developed by Elinor Ostrom (2007). The distinctive feature of this framework is the focus on the interactions between subsystems [25]. We opted to use the SES framework because of its interdisciplinary perspective and the different degrees of specificity while looking at the complexity of both social and ecological systems and their interactions [24,26,27].

We focus on a specific case of water governance in the Mediterranean context, and the SES framework acts as a diagnostic tool to assess the sustainability of current water use. The framework, as detailed in the next section, implies the characterization of a set of variables proven to have an explicit impact on the sustainability of the resource in analysis. With the guidance of the SES structure, we aim to gain a better understanding of water governance in farming systems in a specific case study located in Southern Portugal.

We start by providing an overview of previous applications of the SES framework in water governance, afterwards the case study is presented, as well as the description of the methods used to collect data. Next, the SES framework application is described and discussed. The article's last section summarizes the main conclusions achieved.

\section{Water Governance Approaches with the Social-Ecological Systems Framework}

The SES framework is a general framework that aims to analyse the sustainability of an SES by systematically unpacking first-tier core subsystems in terms of the second-tier variables and, and if needed, third-tier variables $[25,28]$. The social-ecological system will be perpetuated if interactions between the different components are sustainable [25]. The first tier comprises the central subsystems, as shown in Figure 1: resource system (RS); resource units (RU), governance systems (GS); and actors (A). These four subsystems are interrelated in several "action situations". The objective is to understand the action situation through the analysis of the interactions of the different subsystems described as interaction (I) and outcomes (O). Related ecosystems (ECO) and the social, economic, and 
political settings (S) are interacting but considered as external to the system boundary. In the second tier, a total of 56 variables is distributed among the core subsystems. These variables were selected based on many empirical studies that demonstrate how they affect interactions and outcomes, moving the SES closer to or further from sustainability [25].

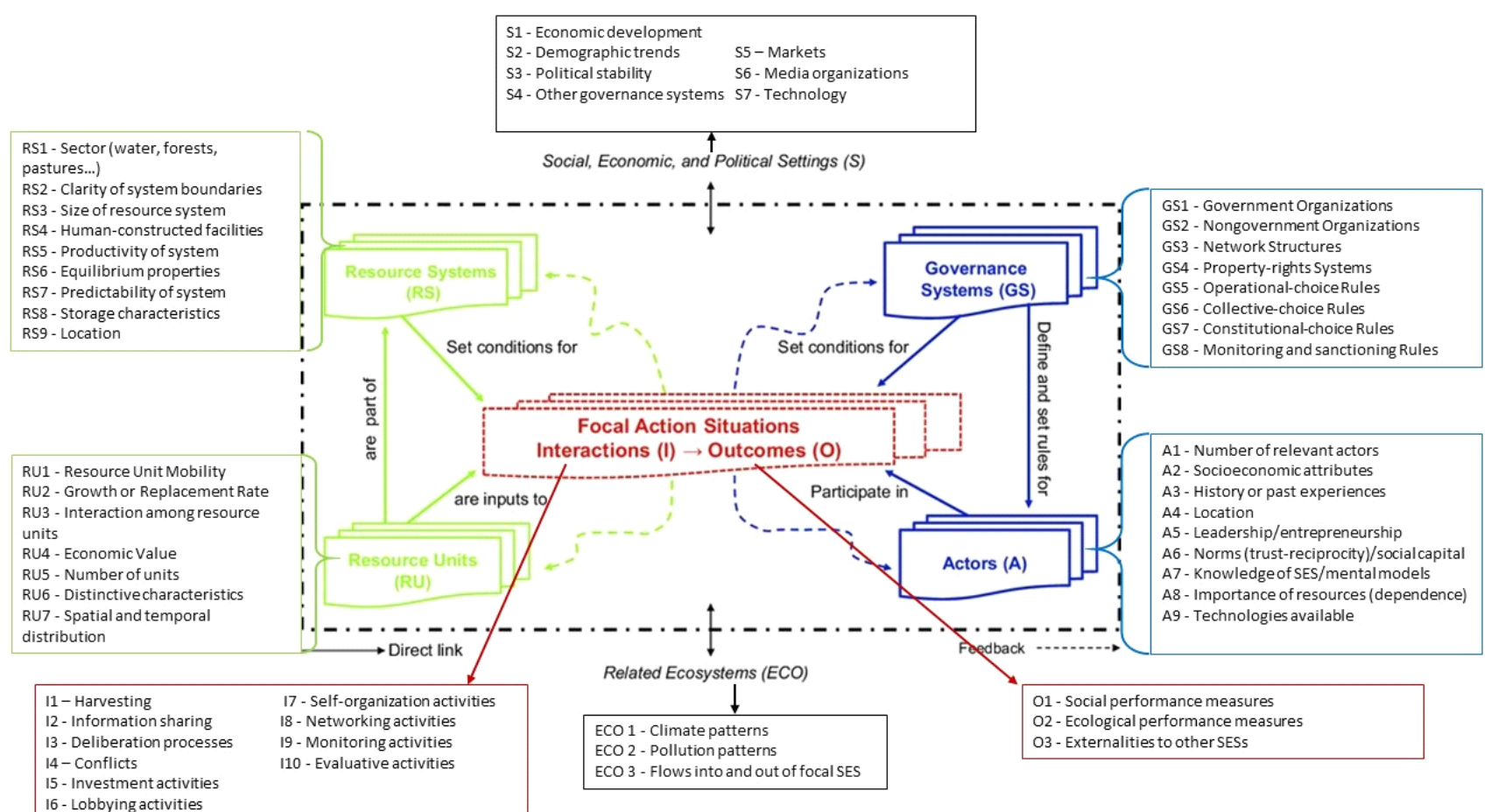

Figure 1. SES framework and second tiers (source: McGinnis and Ostrom, 2014).

The SES framework has been used in studies related to water use and management focused on irrigation [29-31], aquaculture [32,33], water public supply management [34-36], and water availability for human supply [37-39].

Previous studies that used the framework to contextualize water governance problems emphasized the importance of interactions between RS and GS [40,41]. In some types of water systems, the limits (RS2) are not always clear, as is the case with aquifers, which can make it difficult to apply rules and, mainly, to monitor water availability and quality (GS 6-8) [40]. The existence of collective actions is facilitated when the systems are smaller and with clearer limits, as in these cases it is possible to control the number of users and monitor their usage (RS7, RU2) [30]. In addition, network structures (GS3) are easier to develop when the system's size and location (RS3, RS9) allow for greater interaction between different organizations and actors [39]. Local leaders (A5) and the capacity to selforganize (I7) have positive effects on monitoring and operationalization of management activities [31,40]. The creation of non-governmental organizations, such as unions and associations (GS2, A6, I8), allows for the exchange of knowledge (I2) and promotes capacity development [38].

Structures for capturing and storing water (RS4) improve organizational capacity and promote collective action (GS3, A5) due to the need for defining rules of use, with implications for system productivity (RS5) [41]. The system's size (RS3) also influences governance capacity, and larger systems require greater performance and integration of government agencies (GS1, GS2) [40]. The balance of the system (RS6) depends on storage characteristics (RS8) and recharge rates (RU2) [31,41]. Active monitoring systems are important but difficult when the limits of the water system are unclear.

The economic value of water resources (RU4) varies, considering not only the environmental characteristics but also the history (A3) and socioeconomic attributes (A2) [36]. 
In arid regions, there is a greater concern with water resources and the need to invest in storage structures (irrigation structures, dams) to overcome harsh climatic conditions (RS5) [31].

\section{The Case Study}

The case study includes three municipalities located in the southeast of Portugal (Alcoutim, Mértola, and Serpa; Figure 2). The use of a case study that clusters three municipalities is explained by the fact that they are all included in the hydrographic basin of Guadiana and are crossed by the Guadiana River. Therefore, they represent a typical case in water governance where the resource is shared and the use in one of these territories affects the use in the others. Further, the traditional farming systems are common between the three municipalities, while the development strategies, specifically related to water use, vary.

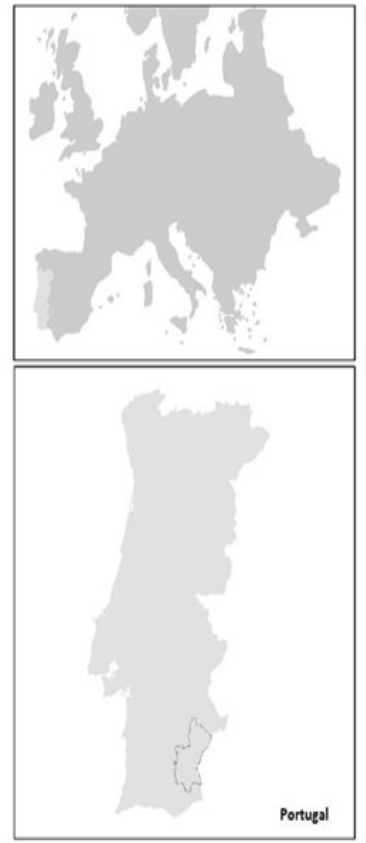

a)

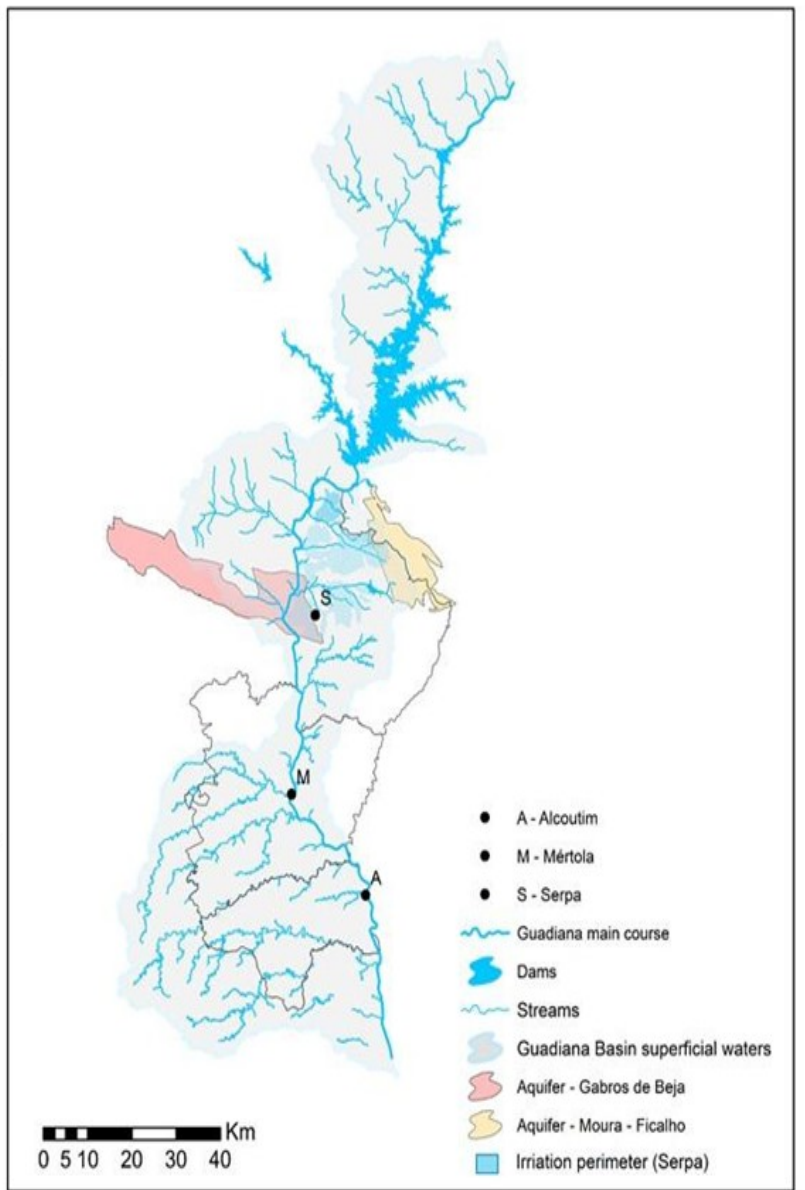

b)

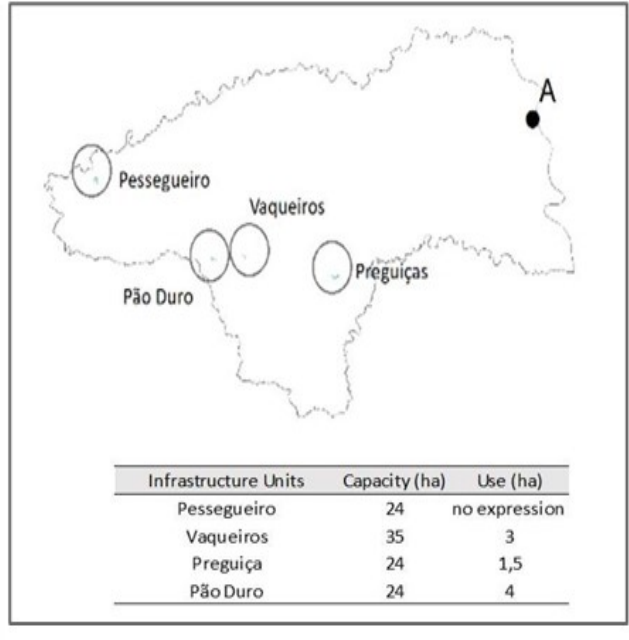

c)

Figure 2. (a) Location of the study area, (b) water resources within the case study, and (c) location of existing dams.

The Alqueva dam—-the largest artificial lake in Europe-follows the Guadiana River along $83 \mathrm{~km}$ of its main course and irrigates 23,927 ha in the northern region of Serpa. In the remaining municipalities, agriculture is mostly rainfed or supported by small irrigation infrastructures. These territories face common challenges, such as water scarcity and management, intensification in more productive areas, and abandonment of marginal territories [42,43]. Added to this scenario is the vulnerability of the Mediterranean to climate change $[44,45]$. 


\section{Data Collection for the Application of the SES Framework in the Case Study}

The application of the SES framework to assess the sustainability of water governance of the farming systems within the case study was done by combining data from two main sources: literature review, and content analysis of semi-structured interviews with territorial actors (that is, actors with an explicit role in territorial development). The interview script was divided into three sections:

- Main farming systems in actors' perspectives;

- Changes in the land systems over the past 10 years and what explains those changes;

- Interactions between water use in different farming systems.

Key territorial actors were identified through the examination of active associations, cooperatives, and organizations related to farming. A similar process was used to identify other relevant institutions acting at the local and regional levels. This identification process continued during the interviewing process through snowball sampling [46]. In total, 22 interviews were conducted in person (one interview was considered, in the cases where more than one person from the same institution was interviewed simultaneously). The data collection took place between October 2018 and April 2019. Content analysis of the transcripts of the interviews was used to identify recurrent features, organizing them by frequency of reference in distinct interviews [47]. The analysis was conducted with the software IRAMUTEQ, a linguistic software based on R and Python. The software conducts a categorization of interviewees' discourses, considering mainly the active forms (names, verbs, adjectives, and some adverbs). Two analyses were performed: Similitude Analysis, and Descending Hierarchical Classification. The first one is based on graph theory, which identifies the co-occurrences between words (represented by the Chi-square of association), helping to identify the patterns of connectedness among the words and the structure of social representations underpinning the speeches [48]. The latter is a divisive hierarchical clustering algorithm that identifies co-occurrences of the active forms and regroups them into classes, ensuring maximum similarity within classes and maximum dissimilarity between classes [49].

The literature review was conducted using Science Direct, Web of Science, and Google Scholar databases and the search terms "water governance" and "agriculture", "farming systems" and "Guadiana basin". Technical reports regarding the basin management plans, and territorial development plans were also consulted. This review was used to compose the characterization of the framework variables and compare the data collected during the interviews.

\section{Results}

Based on the literature review (all references identified in Table 1) and the content analysis of the interviews, 33 of the 52 variables of the SES were characterized and are presented in three subsections: RS and RU; A and GS; I and O. In Table 1, we present the characterization of the second-tier variables of the SES framework, aiming to better disentangle the current situation of water governance in the case study. 
Table 1. Characterization of second-tier variables in the case study.

\begin{tabular}{|c|c|c|c|}
\hline First-Tier Variables & Second-Tier Variables & Case Study Characterization & Information Source \\
\hline \multirow{7}{*}{ Resources Systems } & $\begin{array}{l}\text { Clarity of system } \\
\text { boundaries (RS2) }\end{array}$ & \multirow{2}{*}{$\begin{array}{c}\text { The boundaries of the system are clear and } \\
\text { comprise a large area of the Guadiana basin. } \\
\text { In Portugal, the Guadiana basin covers } \\
11,534.13 \mathrm{~km}^{2} .\end{array}$} & \multirow[t]{2}{*}[50]{} \\
\hline & $\begin{array}{l}\text { Size of resource system } \\
\text { (RS3) }\end{array}$ & & \\
\hline & $\begin{array}{l}\text { Human-constructed } \\
\text { facilities (RS4) }\end{array}$ & $\begin{array}{l}\text { Four hydro-agricultural structures in Alcoutim } \\
\text { territory (Figure 2c) and Alqueva dam. }\end{array}$ & {$[51,52]$} \\
\hline & $\begin{array}{l}\text { Productivity of the system } \\
\text { (RS5) }\end{array}$ & $\begin{array}{l}\text { The productivity of the system is linked to the } \\
\text { use of water in agriculture, where a dual scenario } \\
\text { prevails: expansion of intensive agriculture, due } \\
\text { to the availability of irrigation and regions of } \\
\text { underutilization of available resources. }\end{array}$ & $\begin{array}{l}\text { Interviews, } \\
{[51,52]}\end{array}$ \\
\hline & Equilibrium of system (RS6) & $\begin{array}{l}\text { The system is described as in disequilibrium. In } \\
\text { Alcoutim, the existing hydro-agricultural } \\
\text { structures are underutilized concerning the } \\
\text { capacity for which they were designed } \\
\text { (Figure 2c). The harsh climate and frequent } \\
\text { droughts induce periods of water scarcity, and } \\
\text { the control of groundwater exploitation } \\
\text { is incipient. }\end{array}$ & $\begin{array}{l}{[53-56]} \\
{[52]}\end{array}$ \\
\hline & $\begin{array}{l}\text { Predictability of system } \\
\text { dynamics (RS7) }\end{array}$ & $\begin{array}{l}\text { There is a reasonable capacity to predict the } \\
\text { dynamics of the system, it is consensual that } \\
\text { exploitation surpasses the recharging capacity of } \\
\text { the basin and scenarios of climate change point } \\
\text { to an increase in water scarcity. }\end{array}$ & [17] \\
\hline & Location (RS9) & $\begin{array}{l}\text { Guadiana basin is larger than the boundaries of } \\
\text { our case study. Yet, human activity of all the } \\
\text { basin affects the conditions of water availability } \\
\text { and quality within the case study. }\end{array}$ & Figure 2 \\
\hline \multirow{3}{*}{ Resources Units } & $\begin{array}{l}\text { Resource unity mobility } \\
\text { (RU1) }\end{array}$ & $\begin{array}{l}\text { Water is a highly mobile resource. Along the } \\
\text { basin from Spain to Portugal water is heavily } \\
\text { extracted and contaminated mainly due to } \\
\text { agriculture activities. }\end{array}$ & [50] \\
\hline & $\begin{array}{l}\text { Growth and replacement } \\
\text { rate (RU2) }\end{array}$ & $\begin{array}{l}\text { Between } 2017 \text { and } 2018 \text {, severe drought led to a } \\
10 \% \text { decrease in storage volumes in the Guadiana } \\
\text { basin. It is estimated that for the next few years } \\
\text { there will be a } 15 \text { to } 30 \% \text { percent decrease in } \\
\text { precipitation in the region. The replacement rate } \\
\text { is variable and described as decreasing as } \\
\text { climate conditions become more severe. }\end{array}$ & {$[50,55]$} \\
\hline & $\begin{array}{l}\text { Interaction between } \\
\text { resource units (RU3) }\end{array}$ & $\begin{array}{c}\text { The high degree of interaction between the } \\
\text { different units-aquifers, rivers. Few studies } \\
\text { reflect concerns about the influence of surface } \\
\text { water use on groundwater resources. Low or no } \\
\text { interaction between the units of } \\
\text { hydro-agricultural facilities and the EFMA } \\
\text { irrigation area. }\end{array}$ & [56-58] \\
\hline
\end{tabular}


Table 1. Cont.

\begin{tabular}{llll}
\hline First-Tier Variables & Second-Tier Variables & Case Study Characterization & Information Source
\end{tabular}

Although there is consensus that water is extremely important for the case study, its economic value is disputed. Several actors highlighted that the price that farmers pay for water use is lower than the costs to maintain the existing infrastructures. Without governmental support, the water price would not allow

Economic value (RU4) investments in place of intensive agriculture.

Despite the use of technology towards efficient irrigation, such a development path was considered unsustainable, without beneficial impacts on socio-economic development because it will not sustain people in the territory for the long run.

1 basin

Numbers of units (RU5)
Interviews

[59]
Spatial and temporal distribution (RU7)
Governmental organizations (GS1)

Nongovernmental organizations (GS2)

Network structure (GS3)

Property-rights systems (GS4)

Governance Systems

* Operational-choice rules (GS5)

$$
2 \text { aquifers }
$$

4 hydro-agricultural structures (Alcoutim)

Spatial distribution of water resources is steady and identified, yet temporal distribution varies due to strong seasonality of precipitation, a strong inter-annual variability, with tendencies years, due to the aggravation of global climate change.

Full description in Table 2.

Surveys

[50]

A clear network structure was not identified.

Performed by different actors within the municipalities, but no network between the municipalities (regional level) was identified.

Most of the land is privately owned, with a larger average property size in Mértola, and smaller in Serpa and Alcoutim.

Figure 2, [52]

revious work describes the rules in use.
No previous work describes the rules in use.
However, there are irrigation associations that we were not able to reach and interview during the present study. Other actors describe these associations as having a very small impact on the rules of use.
** Collective-choice rules (GS6)
At the national level, the Water Law (Decreto-Lei n. ${ }^{\circ} 130 / 2012$ ) defines uses and plans (National Water Plan-Decreto-Lei n. ${ }^{\circ}$ 76/2016).

Guidelines for agricultural uses are also defined at national levels. Management Plans and Development Programs act at regional scales.
Decreto-Lei n. $^{\circ}$

130/2012, Decreto-Lei n. ${ }^{\circ} 42 / 2016$,

Decreto-Lei . $^{\circ}$ 44/2017,

Lei n. ${ }^{\circ}$ 58/2005,

Decreto-Lei n. ${ }^{\circ}$ 76/2016,

Decreto-Lei n. ${ }^{\circ}$ 68/99 
Table 1. Cont.

\begin{tabular}{|c|c|c|c|}
\hline First-Tier Variables & Second-Tier Variables & Case Study Characterization & Information Source \\
\hline \multirow{4}{*}{ Actors } & Numbers of actors (A1) & $\begin{array}{l}\text { There is no exact number of actors that should be } \\
\text { involved in the governance of these water } \\
\text { resources, but the characterization is presented } \\
\text { in Table } 2 .\end{array}$ & $\begin{array}{c}\text { Interviews, website } \\
\text { reviews }\end{array}$ \\
\hline & $\begin{array}{l}\text { Leadership and } \\
\text { entrepreneurship (A5) }\end{array}$ & $\begin{array}{l}\text { No leaders were identified in water resources } \\
\text { governance. Yet Alqueva management } \\
\text { consortium (EDIA) and ARH (Administration of } \\
\text { Hydrographic Region of Alentejo) are key players. }\end{array}$ & Interviews \\
\hline & $\begin{array}{l}\text { Knowledge of SES, mental } \\
\text { models (A7) }\end{array}$ & $\begin{array}{l}\text { Actors described the system in a very } \\
\text { consensus-based manner; therefore, there is } \\
\text { cohesion in regard to the limits of the system and } \\
\text { what is at stake. Nonetheless, we found } \\
\text { divergence on the strategies for territorial } \\
\text { development: (1) aims to increase water } \\
\text { retention and invest in intensive agriculture, (2) } \\
\text { aims to increase the efficient use of water } \\
\text { resources and invest in extensive agriculture. }\end{array}$ & $\begin{array}{c}\text { Interviews, Figures } 3 \\
\text { and } 4\end{array}$ \\
\hline & Technologies available (A9) & $\begin{array}{l}\text { Individual initiatives in the development of } \\
\text { strategies and adoption of technologies that } \\
\text { allow the storage of water in the territory (small } \\
\text { dams) without necessarily depending on the } \\
\text { construction of large reservoirs and dams and } \\
\text { dependence on responsible entities. }\end{array}$ & Interviews \\
\hline
\end{tabular}

The lack of networking and communication between actors were recurrent factors listed in the Information sharing (I2) interviews, specifically between science and the practice of farming. Therefore, I2 was considered insufficient to improve water governance.

No deliberative processes were identified, agriculture management is mainly privately

Deliberation processes (I3) defined, and water governance occurs with a top-down approach by the public and semi-public institutions.

Interactions

Outcomes

\begin{tabular}{c}
\hline Conflicts (I4) \\
\hline Investments activities (I5) \\
Lobbying activities (I6) \\
\hline $\begin{array}{c}\text { Self-organization activities } \\
\text { (I7) }\end{array}$ \\
\hline Networking activities (I8) \\
\hline Monitoring activities (I9) \\
Social performance \\
measures (O1) \\
$\begin{array}{c}\text { Ecological performance } \\
\text { measures (O2) }\end{array}$
\end{tabular}

No explicit conflict was identified, but perspectives on development are very often opposing.
Interviews, website reviews Mainly in dam constructions in the past.

The collective initiative mainly focuses on preserving traditional farming activities and increasing social capital.

Creation of local food chains and self-consumption initiatives mainly at schools, mostly in Mértola municipality.

No long-term networking, monitoring of evaluative actives were identified.

Clear existence of social capital, even though problems related to depopulation, aging of producers, and desertification conditions prevail. Impact on the ecological conditions of the estuary has been described. 


\subsection{Resource Unit and System}

The case study is located (RS2, 3, and 9) in the Guadiana basin, which covers a total area of $66,999.83 \mathrm{~km}^{2}$, of which $11,534.13 \mathrm{~km}^{2}(17.22 \%)$ are located in Portugal. The region includes two aquifers (RU5), namely Moura-Ficalho and Gabros da Beja, partially located in Serpa (Figure 2b). We acknowledge that precipitation and other climatic factors influence water availability and quality, yet our analysis focuses on the characterization of these RU considering the effect that governance can have, since governance models can be changed or improved.

In our study, we consider the productivity of the water resources (RS5) linked to their use in farming. Water availability in Serpa is greater than in other municipalities because of the Alqueva dam. This dam was an important landmark for the country and in particular for the Alentejo region, deeply changing the surrounding landscape and allowing new farming strategies and crops. The plans to build the Alqueva dam started half a century ago, as a multipurpose structure that, in addition to irrigation, was intended to act as a water reservoir and recreation place. Currently, $21.64 \%(23,927 \mathrm{ha})$ of Serpa's territory is under the irrigation project of Alqueva. Of these areas, more than $75 \%$ is occupied by olive groves, of which 13,554 ha (56\%) are intensive olive groves and 3647 ha $(15 \%)$ super intensive. Such land system dynamics in Serpa depict a trend towards intensification. In 2009 , Serpa accounted for 9045 ha of the irrigable area and 8244 ha of average irrigated area for 3 years, while in Mértola and Alcoutim these values were 692 ha and 52 ha, respectively, for the irrigable area. In Mértola there is no public infrastructure dedicated to agricultural irrigation, and irrigated agriculture is done by individual and private investments in small ponds for water storage or water wells that extract groundwater. The lack of access to water infrastructure is likely to have influenced Mértola's explicit strategy to promote rainfed farming systems. Alcoutim has four micro dams (RS4) with a potential for irrigation ranging between 24 ha and 35 ha (Figure 4). All the structures are being used below their capacity, irrigating a total of 8.5 hectares. Although the micro-dams in Alcoutim were built mainly to serve small-scale irrigated farming, the main use is public supply and firefighting.

Despite the heterogeneity of the three municipalities that constitute the case study, there is a reasonable capacity to predict the systems dynamics (RS7), and a consensual perspective that uses surpasses the recharging capacity of the basin, and that scenarios of climate change point into an increase in water scarcity. There is an accentuated seasonality of precipitation, with strong interannual irregularity (RU7) and the predominance of semiarid climatic conditions. In terms of replacement rate (RU2), the Moura-Ficalho aquifer has an average annual recharge of $17.15 \mathrm{hm}^{3}$ (RU2). Its annual exploitation is estimated at $5.04 \mathrm{hm}^{3}$, mainly for urban supply $\left(3.2 \mathrm{hm}^{3} /\right.$ year $)$ and agricultural use $\left(1.35 \mathrm{hm}^{3} /\right.$ year$)$. In the case of the Gabros de Beja aquifer, agricultural use surpasses urban supply with operational fractions of 5.06 and $4.78 \mathrm{hm}^{3}$ /year, respectively. In addition to the quantity, another important feature is the quality of these RU. The Gabros de Beja aquifer has its chemical status classified as "mediocre", with levels of nitrate that make it unfit for human consumption. In addition, there is an increase in episodes of extreme drought, with possible implications for replacement rates in the future. Interrelations between the quality of surface and groundwater aquifers of the basin indicate the need for maintaining aquifer-dependent ecosystems. The construction of dams, namely Alqueva and Pedrogão (23 km downstream of the Alqueva dam), increased the existing challenges by altering the discharge flow along Guadiana and effluents, and the coastal and estuarine ecosystems. Studies, referred to in Table 1, demonstrate that in the estuarine region of the Guadiana basin, the changes in water flow altered the concentration of nutrients, salinity, and, consequently, the distribution and composition of aquatic fauna. The increase in the concentration of nutrients and organic descriptors resulting from the intensification of agricultural activities in the region has also been registered. 


\subsection{Actors and Governance System}

Table 2 describes the typologies of actors involved in water governance in the case study area. Several national and local governmental institutions (GS1) are implicated. Yet, a greater active role was found at the municipal level where municipalities are building strategies, promoting and supporting local initiatives, communicating with several other actors, and facilitating communication between them. The presence and activities of nongovernmental institutions (GS2) were also visible and in close collaboration with local GS1. Such collaboration decreased when territorial coverage of GS1 increased. Policymakers and decision-making were described as top-down and distant from local needs and not considering the social-ecological context. The Enterprise of management of Alqueva Dam (EDIA) was described as a key public-private player.

In terms of management of water resources, non-governmental organizations seek to increase and solidify water collection and storage strategies, as well as to disassociate the development of agricultural activities from the use of irrigation. Between the three municipalities, Mértola stands out having an explicit and articulated discourse towards rainfed farming systems, considered adapted to the climatic conditions and changes foreseen in the future. Identified private initiatives aim to increase water availability mainly by regenerating the soil ecosystem, increasing its functional biodiversity, organic matter, and subsequently water retention capacity (agricultural practices concerned with water conservation such as swales and ponds). In Alcoutim, the perspectives found were two-fold in a desire to increase water availability and the development of economically viable farming systems (by intensification and/or promoting traditional farming systems). Irrigation cooperatives were identified but described as almost inactive. We were able to interview one of them that confirmed such a perspective, by stating an inability to build a producers' network due to the distance between farms, depopulation, and subsequent decline in farming. The existence of underutilized hydro-agricultural structures was also justified by the interviewees due to the absence of interconnections between the water reservoirs and the farmed land. Such disconnection was also the reason why in Alcoutim, despite the existence of these structures, there is a call for more dams localized in areas considered more suitable for farming.

The Guadiana basin is identified as a management unit in the National Water Resources Plan, and there is a management plan for the region. The case study is integrated within this management plan, yet no evident link to such a regulatory framework was identified during the interviews. The relationship between farming and the rational use of water resources is foreseen in the management plan for Guadiana Basin and other regulatory instruments.

Figures 3 and 4 help us to understand the existing mental models (A7) regarding water governance. The words most used by the interviewees were related to water availability, property size, and farming crops, especially olive groves. Based on the similarity analysis, Figure 3 presents a graph of forms and connections. The term water has a central role and is directly linked to production, property size, and crop types. The relationship with the word "year" is also worthy of mention, since seasonality is a striking feature of the territory, as well as climate change and, consequently, local water availability. The hierarchical classification (Figure 4) allowed us to better schematize the main concerns unveiled during the interviews in three themes: management and farming systems, water availability, and transformation and commercialization. The "management and farming systems" theme included terms related to the size of the farms. The majority are family-managed farms, but the emergence of land lease companies and external investments are driving changes in the traditional landscape. In addition to size, property ownership was also a key issue. In Alcoutim, properties were considered too small and sometimes scattered, which hinders economically viable farming business models. In Serpa, properties are being sold to large companies, inducing land agglomeration, owned or rented by enterprises decoupled from the social context and not contributing to the necessary vitalization of local communities and social capital. 
Table 2. Actors and their characteristics constructed with the data collected by the interviews.

\begin{tabular}{|c|c|c|c|}
\hline Actors & Position & Action & Control \\
\hline $\begin{array}{l}\text { Governmental } \\
\text { institutions }\end{array}$ & $\begin{array}{l}\text { Portuguese Environment Agency } \\
\text { Regional Office for Agriculture and Fisheries } \\
\text { Administration of the Hydrographic Region } \\
\text { Commission of Coordination and Regional } \\
\text { Development } \\
\text { Forestry and Nature Conservation Institute } \\
\text { Municipalities }\end{array}$ & $\begin{array}{l}\text { Responsibility for putting in practice } \\
\text { policy guidelines provided by the } \\
\text { policymakers. } \\
\text { Intermediaries between landowners, } \\
\text { managers and policymakers. } \\
\text { The main purpose of the inspection is } \\
\text { to guarantee the multiple uses } \\
\text { foreseen for water. }\end{array}$ & $\begin{array}{l}\text { They act in compliance with the } \\
\text { legislation, guarantee that the } \\
\text { regulation is being met. } \\
\text { Promote the discussion of best } \\
\text { practices regarding water use and } \\
\text { local planning. } \\
\text { Control and monitor the use of } \\
\text { water resources. }\end{array}$ \\
\hline $\begin{array}{l}\text { Nongovernmental } \\
\text { organizations }\end{array}$ & $\begin{array}{l}\text { Forest Production Association } \\
\text { Irrigation Cooperatives } \\
\text { Local Action Groups } \\
\text { Association of Patrimony Defence } \\
\text { Farmers Association }\end{array}$ & $\begin{array}{l}\text { Promotion of water use strategies in } \\
\text { agricultural activity. } \\
\text { Support to producers/farmers in the } \\
\text { management of water resources. }\end{array}$ & $\begin{array}{l}\text { No control in the use of water, but } \\
\text { can support/promote strategies and } \\
\text { collective actions. }\end{array}$ \\
\hline Policymakers & $\begin{array}{l}\text { Ministry of Agriculture, Forestry, and Rural } \\
\text { Development } \\
\text { Ministry of Environment and Energy } \\
\text { Transition }\end{array}$ & $\begin{array}{l}\text { Organization of plans and } \\
\text { instruments to ensure that the Water } \\
\text { Law is applied in the territory. }\end{array}$ & Control law and regulation design. \\
\hline $\begin{array}{l}\text { Private } \\
\text { institutions }\end{array}$ & $\begin{array}{l}\text { Enterprise of management of Alqueva Dam } \\
\text { (EDIA) }\end{array}$ & $\begin{array}{l}\text { Promotes the expansion and } \\
\text { monitoring of the irrigation project of } \\
\text { Alqueva. }\end{array}$ & $\begin{array}{l}\text { No control over policymaking, but } \\
\text { they act to promote the distribution } \\
\text { and controlled use of water } \\
\text { resources for irrigation. }\end{array}$ \\
\hline Users & $\begin{array}{l}\text { Landowners } \\
\text { Farmers }\end{array}$ & Use water resources. & $\begin{array}{l}\text { They control the use of water } \\
\text { resources and management } \\
\text { practices implemented in each } \\
\text { farming system. }\end{array}$ \\
\hline
\end{tabular}

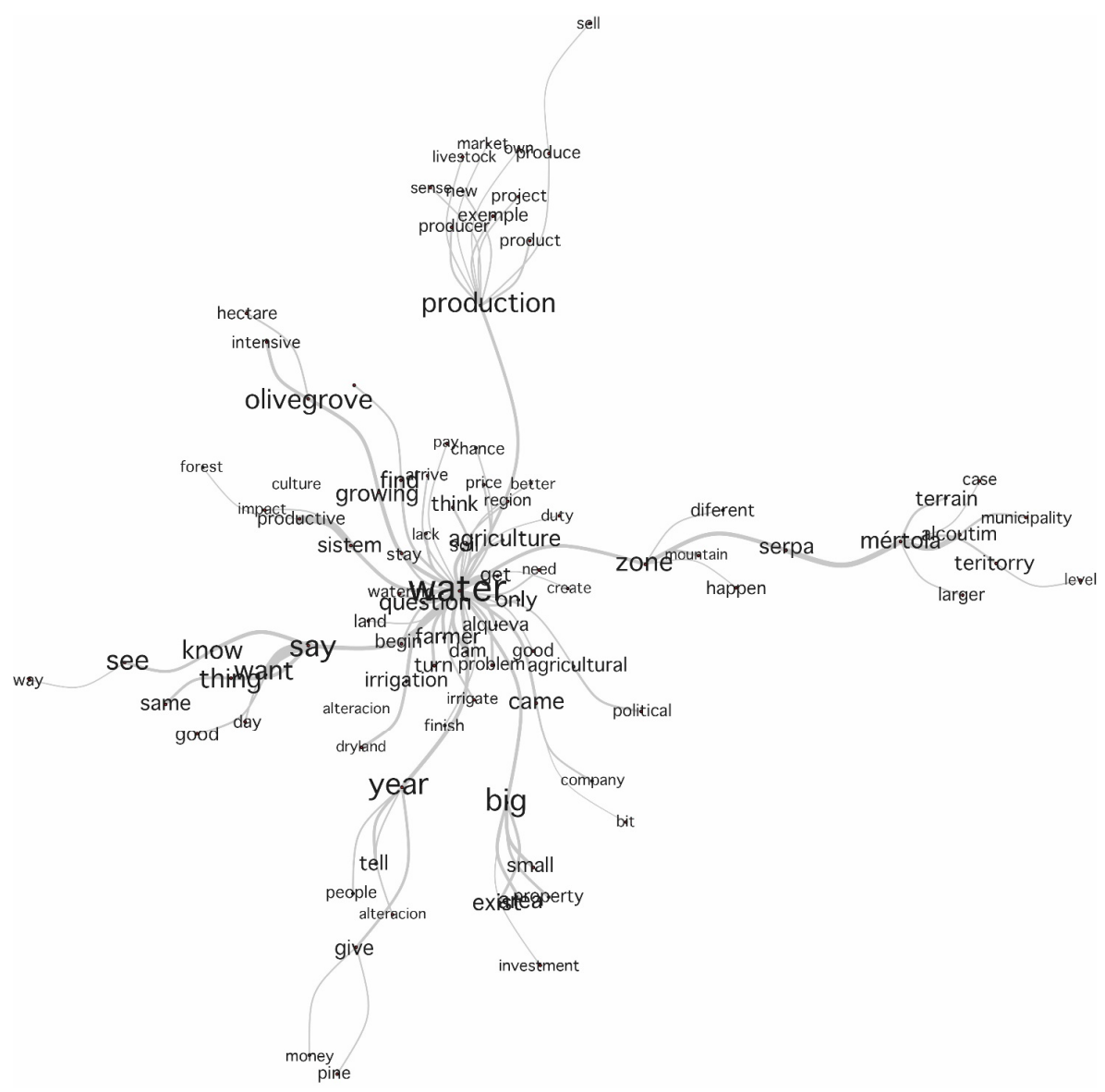

Figure 3. Graph of similarities applied to the active forms (translated from Portuguese). The strength of the relationship between the forms is represented by the thickness of the lines, while the font size of the forms indicates the frequency of occurrences of the forms. Source: research data analysed by IRAMUTEQ. 


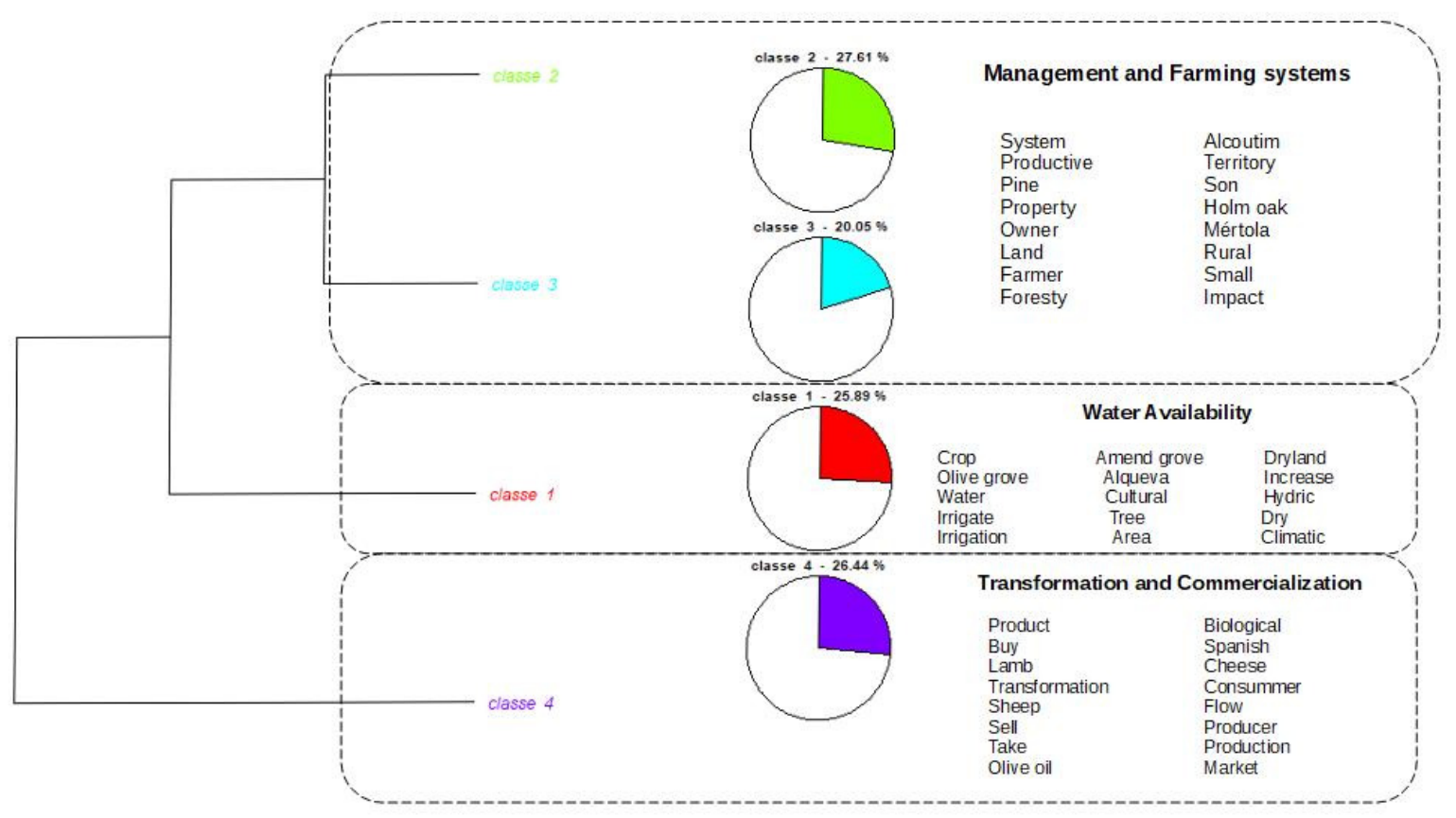

Figure 4. Classes were obtained with the hierarchical classification method ALCESTE. Classes 2 and 3 were grouped and named "management and farming systems", class 1 "water availability", and class 4 "transformation and commercialization". Source: research data analysed by IRAMUTEQ.

\section{Discussion}

Our main findings can be summarized in three overall conclusions:

- The increase of water availability to farming might not solve the sustainability problems of the territory;

- Water is not managed commonly, and almost no evidence of collective and integrated governance was found;

- Water governance should consider the particularities of each municipality while promoting their integration towards a sustainable decision-making system.

The results attained for the theme "water availability" depict the worries in regard to farming production in a region suffering from water scarcity. The emergence of irrigated land in the northern region of Serpa and consequent expansion and intensification of olive production was mostly described as a worrying trend. These worries were linked not only with the loss of traditional and rainfed agriculture but also with the cost of water and the sustainability of water-dependent farming systems, under the climate change projections. On the other hand, in this perspective, water is understood as a way to develop agriculture. The construction of dams is understood as a strategy to increase water availability. Nonetheless, the negative impacts of securing water using dams were also identified, with references to changes in river flow, and aquatic biota and ichthyofauna. A willingness to intensify agricultural activities and take advantage of the water available was identified, including the need to justify the financial investment done so far in the construction of dams (in Alcoutim). On the other hand, local development was described as not dependent only on the water made available by dams but also on traditional farming systems well adapted to water scarcity. Local development was described as challenging due to depopulation and lack of collaboration (GS3) between some important actors, including farmers.

In the theme "transformation and commercialization", we found a common concern regarding the processing and marketing of local farming products due to the lack of infrastructures. As an example, slaughterhouses are absent in the territory, and even small producers have difficulty in selling the full amount of products produced due to the lack 
of commercialization channels. The creation of networks for trading local production was considered necessary. Further, the quality of such products should be promoted, and certification was referred to as a possible strategy.

\subsection{Interactions and Outcomes}

Information sharing (I2) does not seem to be sufficient to consensually define a farming strategy for the region and improve water use and respective governance. Knowledge and dissemination were considered lacking, and a call for extension services in these territories was identified by several interviewees. Decision-making in the farming sector (I3) was described as mostly private and individual, while decisions regarding water management were considered to be carried out in a top-down manner by the national and regional governmental institutions. We found mental models on future development pathways to be diverse and often difficult to integrate into a common and collective format. Despite the divergence found, no explicit conflict was identified (I4). About investment activities (I5), we found a desire to invest in the construction of dams and increase the interconnection between water reservoirs and farming land. Strong lobbying activities (I6) were not identified, but the non-governmental institutions showed strong dynamics and connection with local governments, mainly to preserve traditional agricultural activities and increase social capital. Self-organized (I7) initiatives were identified, including the creation of local food chains and self-consumption initiatives, mainly in schools. No long-term network monitoring of evaluative activities was identified (I8 to I10).

In terms of results (O1 and O2), the study showed that there is a strong effort by governmental and non-governmental institutions to improve ecological results, and the existence of social capital is clear.

\subsection{The Impact of Increasing Water Availability}

To the best of our knowledge, very few studies have focused on the social and economic components of water governance in the case study [54,64]. Yet, the impacts of farming intensification in such components have been discussed before [65,66], although we did not find a systematized overview of how farmers concretely manage their water resources. At the municipal level, Mértola was the one with a stronger and well-defined discourse towards water governance (dissemination of water conservation strategies in the territory prevails compared to the exploration of new dams); however, we were not able to assess the representativeness of such strategies. Water availability on the hand and scarcity on the other were found to be important drivers of changes in farming systems and to inform how actors envision their territory $[61,67]$. Water reservoirs such as dams and access to irrigation technology can play a role in counteracting water scarcity $[18,68]$. Yet, these infrastructures and their management bring social and environmental stakes that need to be taken into consideration. Silveira et al. (2018), focusing on olive productions, provide an overview of such impacts mainly in regard to actor-networks that are rapidly changing previously existing links across economy, community, and ecology in the region. The authors concluded that the water made available by the Alqueva dam and invested in olive production in a fraction of Serpa territory is promoting a double decoupling process: decoupling from the surrounding communities, in a context of local communities shrinking through emigration and aging, and a parallel decoupling from the underpinning ecological processes. Although in the remaining municipalities of our case study, this characterization is not valid, the processes described show that increased access to water also increases the susceptibility to undesirable territorial dynamics. Access to irrigation in Serpa introduced new farming dynamics on the use and quality of water, but also new social and economic issues $[58,65]$. Overexploitation and contamination of water can become increasingly relevant problems $[57,69]$. Intensification of farming and water use may increase the territory's competitiveness, but its short-term labour requirements create precarious positions, often filled by immigrants living under inadequate living standards [65]. Further, the increase in water availability is also changing the relationship between landowners 
and land, attracting foreign investors and land aggregation for larger farms [65]. The abandonment of traditional extensive farming and the increased intensification represents not only a loss in traditional and context-based farming knowledge but also threatens cultural landscapes [43]. In our study, we found that water availability does not solve problems of abandonment and depopulation that are acute issues of the case study [61].

\subsection{How Is the Governance of Water Done?}

Water governance does not seem to be developed by collective actions. Decisions and strategies are mostly developed individually or in a centralized format using a top-down approach. Between municipalities, Mértola stood out by the actor-networks identified, clearly leading a strategy based on the ecological and socio-economic assets of the municipality without considering that the increase in water availability by investments in infrastructure such as dams will solve the existing challenges. We were not able to assess the representativeness of such a strategy in the overall Mértola territory, but the monitoring of such dynamics would be of great value for research in water governance.

The difficulty in reaching and interviewing representatives of a specific group of actors and the lack of literature indicates that the research agenda in the overall territory should include monitoring grass-roots initiatives. Yet, results show that leadership, trust and reciprocity, information sharing, and networking actives are affecting the system and can imply new approaches for water governance in the future.

\subsection{What Could Water Governance for Farming Look like in the Future?}

Water governance is highly contextual and requires a broader understanding beyond the availability of the resource [70].

Water policies and regulations do not appear to have an effective outcome in the territory. Further, the future described by the interviewees indicates that issues of depopulation, water scarcity, and desertification can increase if business as usual continues. The growing depopulation of the territory makes collective actions and the engagement of actors in activities to promote the sustainable use of water resources in farming difficult [38,41]. Although there is no consensual optimal scale to operationalize water governance [71], other studies found higher success in achieving sustainability when various actors from different levels are involved [72,73]. Therefore, this territory will benefit from activities that promote collaboration. Future studies should focus on arriving at a more comprehensive and general overview of who and how many actors are present in the territory and how they can be integrated into a governance format that can sustain water resources. From the characterization of the SES framework variables linked to the biophysical system (system size, productivity, balance) and related structures (storage structures), we understand their relevance in decision making and collective action processes $[33,40]$. Yet, we found that knowledge, rules, and existing governing structures have a small impact on how the biophysical system is managed. The fact that the case study is located at the end of a much larger management unit, the Guadiana basin, increases the governance challenges described [41].

Water management in a large-scale basin, such as the Guadiana, faces problems from different spheres, both in terms of natural and social impacts [74]. Local water characteristics and climate change are directly related to and affected by land use. In this regard, adapting the actions of institutions in water management at a local scale, through greater integration of local departments and strengthening the local cooperative network, can act to promote better management and sustainability of water resources [75].

We argue that the differences we found between the subsystems of the three municipalities show that management on a national (and even regional) scale has not taken into account the specificities of each municipality. Strategies that address particular issues and promote inter-municipal links would benefit the sustainability of the resources at stake. Positive results depend on how we can find forms of cooperation and development in various territories within the same basin. 


\section{Conclusions}

The present study shows the complexity of factors involved in water governance in the farming sector. In this sense, although there is a guiding question (the scarcity of water resources), it is not possible to define a single driver as limiting farming development. Water availability is not an isolated effort to be circumvented for rural development. The repopulation of abandoned territories, the construction of local production and consumption networks, and activities focused on the skills of the territories are strategies that deserve attention in the planning of public policies and governance in the future.

The adoption of the SES framework allowed the exploration of the relationships between the different variables implicated in water governance, while also making explicit the existing knowledge gaps. Therefore, the use of the SES framework contributed to a holistic understanding of the territory and allowed a diagnosis that can direct future research on the subject.

Author Contributions: Conceptualization, T.H. and M.H.G.; Methodology, T.H., M.H.G., and C.E.; writing-original draft preparation, T.H., M.H.G., and C.E.; writing-review and editing, T.H., M.H.G., C.E., and L.M. All authors have read and agreed to the published version of the manuscript.

Funding: This research was supported by the DIVECROP (Land system dynamics in the Mediterranean basin across scales as a relevant indicator for species diversity and local food systems, project ID: 10905), an ARIMNet2 project within an ERA-NET Action financed by the European Union under the Seventh Framework Programme for research, technological development, and demonstration.

Acknowledgments: We would like to thank all the interviewed persons for their interest in this topic and availability.

Conflicts of Interest: The authors declare no conflict of interest.

\section{References}

1. Levidow, L.; Birch, K.; Papaioannou, T. EU agri-innovation policy: Two contending visions of the bio-economy. Crit. Policy Stud. 2012, 6, 40-65. [CrossRef]

2. Driessen, P.P.J.; Dieperink, C.; van Laerhoven, F.; Runhaar, H.A.C.; Vermeulen, W.J.V. Towards a Conceptual Framework for the Study of Shifts in Modes of Environmental Governance-Experiences from The Netherlands. Environ. Policy Gov. 2012, 22, 143-160. [CrossRef]

3. Sandström, C.; Lindahl, K.B.; Sténs, A. Comparing forest governance models. For. Policy Econ. 2017, 77, 1-5. [CrossRef]

4. Lehtinen, A.; Donner-Amnell, J.; Saether, B. Introduction: Northern Forest Regimes and the Challenge of Internationalization. In Politics of Forests-Northern Forest_Industrial Regimes in the Age of Globalization; Amnell, J., Saether, B., Eds.; Ashgate: Aldershot, UK, 2004; pp. 3-30.

5. Ostrom, E. Governing the Commons: The Evolution of Institutions for Collective Action, 1st ed.; Cambridge University Press: Cambridge, UK, 1990.

6. Challies, E.; Newig, J. Sustainability Governance. 2019. Available online: https://sustainability-governance.net/2019/06/14 /what-is-environmental-governance-a-working-definition/ (accessed on 14 June 2019).

7. Toner Cleaver, F. The evolution of Community Water Governance in Uchira, Tanzania: The Implications for Equality of Access, Sustainability, and Effectiveness. Nat. Resour. Forum 2006, 30, 207-218. Available online: http:/ /www3.interscience.wiley.com/ journal/118571654/abstract (accessed on 27 April 2021). [CrossRef]

8. Nakano, Y.; Otsuka, K. Determinants of Household Contributions to Collective Irrigation Management: The Case of The Doho Rice Scheme in Uganda. Environ. Dev. Econ. 2011, 16, 527-551. [CrossRef]

9. Yu, Q.; Wu, W.; Verburg, P.H.; van Vliet, J.; Yang, P.; Zhou, Q.; Tang, H. A survey-based exploration of land-system dynamics in an agricultural region of Northeast China. Agric. Syst. 2013, 121, 106-116. [CrossRef]

10. Wu, W.; Verburg, P.H.; Tang, H. Understanding land system dynamics and its consequences. J. Geogr. Sci. 2018, 28, 1563-1566. [CrossRef]

11. Iglesias, A.; Garrote, L.; Flores, F.; Moneo, M. Challenges to manage the risk of water scarcity and climate change in the Mediterranean. Water Resour. Manag. 2007, 21, 775-788. [CrossRef]

12. Gichenje, H.; Godinho, S. A Climate-smart approach to the implementation of land degradation neutrality within awater catchment area in Kenya. Climate 2019, 7, 136. [CrossRef]

13. Gichenje, H.; Muñoz-rojas, J.; Pinto-Correia, T. Opportunities and Limitations for Achieving Land Degradation-Neutrality through the Current. Land 2019, 8, 115. [CrossRef] 
14. Dudgeon, D.; Arthington, A.H.; Gessner, M.O.; Kawabata, Z.I.; Knowler, D.J.; Lévêque, C.; Naiman, R.J.; Prieur-Richard, A.-H.; Soto, D.; Sullivan, C.A.; et al. Freshwater biodiversity: Importance, threats, status and conservation challenges. Biol. Rev. 2006, 81, 163-182. [CrossRef] [PubMed]

15. Gordon, L.J.; Finlayson, C.M.; Falkenmark, M. Managing water in agriculture for food production and other ecosystem services. Agric. Water Manag. 2010, 97, 512-519. [CrossRef]

16. Tomaz, A.; Patanita, M.; Guerreiro, I.; Boteta, L.; Palma, J.F. Water use and productivity of maize-based cropping systems in the Alqueva Region (Portugal). Cereal Res. Commun. 2017, 45, 711-721. [CrossRef]

17. Costa, J.M.; Egipto, R.; Sánchez-Virosta, A.; Lopes, C.M.; Chaves, M.M. Canopy and soil thermal patterns to support water and heat stress management in vineyards. Agric. Water Manag. 2019, 216, 484-496. [CrossRef]

18. García-Ruiz, J.M.; López-Moreno, I.I.; Vicente-Serrano, S.M.; Lasanta-Martínez, T.; Beguería, S. Mediterranean water resources in a global change scenario. Earth-Sci. Rev. 2011, 105, 121-139. [CrossRef]

19. Kassam, A.; Friedrich, T.; Derpsch, R.; Lahmar, R.; Mrabet, R.; Basch, G.; González-Sánchez, E.J.; Serraj, R. Conservation agriculture in the dry Mediterranean climate. Field Crops Res. 2012, 132, 7-17. [CrossRef]

20. Fader, M.; Shi, S.; Von Bloh, W.; Bondeau, A.; Cramer, W. Mediterranean irrigation under climate change: More efficient irrigation needed to compensate for increases in irrigation water requirements. Hydrol. Earth Syst. Sci. 2016, 20, 953-973. [CrossRef]

21. Seiffert, M.E.B.; Loch, C. Systemic thinking in environmental management: Support for sustainable development. J. Clean. Prod. 2005, 13, 1197-1202. [CrossRef]

22. Gaziulusoy, A.I.; Boyle, C. Proposing a heuristic reflective tool for reviewing literature in transdisciplinary research for sustainability. J. Clean. Prod. 2013, 48, 139-147. [CrossRef]

23. Williams, A.; Kennedy, S.; Philipp, F.; Whiteman, G. Systems thinking: A review of sustainability management research. J. Clean. Prod. 2017, 148, 866-881. [CrossRef]

24. Binder, C.R.; Hinkel, J.; Bots, P.W.G.; Pahl-Wostl, C. Research, part of a Special Feature on A Framework for Analyzing, Comparing, and Diagnosing Social-Ecological Systems Comparison of Frameworks for Analyzing Social-ecological Systems. Ecol. Soc. 2013, 18, 26. [CrossRef]

25. Ostrom, E. A general framework for analyzing sustainability of social-ecological systems. Science 2009, 325, 419-422. [CrossRef] [PubMed]

26. Manring, S.L. The role of universities in developing interdisciplinary action research collaborations to understand and manage resilient social-ecological systems. J. Clean. Prod. 2014, 64, 125-135. [CrossRef]

27. Vogt, J.M.; Epstein, G.B.; Mincey, S.K.; Fischer, B.C.; McCord, P. Putting the "E" in SES: Unpacking the ecology in the ostrom socialecological system framework. Ecol. Soc. 2015, 20, 55. [CrossRef]

28. McGinnis, M.D.; Ostrom, E. Social-ecological system framework: Initial changes and continuing challenges. Ecol. Soc. 2014, 19, 30. [CrossRef]

29. Wang, Y.; Zang, L.; Araral, E. The impacts of land fragmentation on irrigation collective action: Empirical test of the socialecological system framework in China. J. Rural Stud. 2020, 78, 234-244. [CrossRef]

30. McCord, P.; Dell'Angelo, J.; Baldwin, E.; Evans, T. Polycentric Transformation in Kenyan Water Governance: A Dynamic Analysis of Institutional and Social-Ecological Change. Policy Stud. J. 2017, 45, 633-658. [CrossRef]

31. Cox, M. Applying a Social-Ecological System Framework to the Study of the Taos Valley Irrigation System. Hum. Ecol. 2014, 42, 311-324. [CrossRef]

32. Partelow, S.; Jäger, A.; Schlüter, A. Linking Fisher Perceptions to Social-Ecological Context: Mixed Method Application of the SES Framework in Costa Rica. Hum. Ecol. 2021, 49, 187-203. [CrossRef]

33. Partelow, S. A review of the social-ecological systems framework: Applications, methods, modifications, and challenges. Ecol. Soc. 2018, 23, 36. [CrossRef]

34. Silva, A.C.S.; Galvão, C.O.; Silva, G.N.S. Droughts and governance impacts on water scarcity: An analysis in the Brazilian semi-arid. Proc. Int. Assoc. Hydrol. Sci. 2015, 369, 129-134. [CrossRef]

35. Flynn, C.D.; Davidson, C.I. Adapting the social-ecological system framework for urban stormwater management: The case of green infrastructure adoption. Ecol. Soc. 2016, 21, 19. [CrossRef]

36. Bennet, D.; Gosnell, H. Integrating multiple perspectives on payments for ecosystem services through a social-ecological systems framework. Ecol. Econ. 2015, 116, 172-181. [CrossRef]

37. Aggarwal, R.M.; Haglund, L.D. Advancing water sustainability in megacities: Comparative study of São Paulo and Delhi using a social-ecological system framework. Sustainability 2019, 11, 5314. [CrossRef]

38. Naiga, R.; Penker, M.; Hogl, K. Challenging pathways to safe water access in rural Uganda: From supply to demand-driven water governance. Int. J. Commons 2015, 9, 237. [CrossRef]

39. Madrigal, R.; Alpízar, F.; Schlüter, A. Determinants of Performance of Community-Based Drinking Water Organizations. World Dev. 2011, 39, 1663-1675. [CrossRef]

40. Falk, T.; Lohmann, D.; Azebaze, N. Congruence of appropriation and provision in collective water provision in Central Namibia. Int. J. Commons 2016, 10, 71-118.

41. Partelow, S.; Senff, P.; Buhari, N.; Schlüter, A. Operationalizing the social-ecological systems framework in pond aquaculture. Int. J. Commons 2018, 12, 485-518. [CrossRef] 
42. Caraveli, H. A comparative analysis on intensification and extensification in mediterranean agriculture: Dilemmas for LFAs policy. J. Rural Stud. 2000, 16, 231-242. [CrossRef]

43. Nainggolan, D.; de Vente, J.; Boix-Fayos, C.; Termansen, M.; Hubacek, K.; Reed, M.S. Afforestation, agricultural abandonment and intensification: Competing trajectories in semi-arid Mediterranean agro-ecosystems. Agric. Ecosyst. Environ. 2012, 159, 90-104. [CrossRef]

44. Iglesias, A.; Mougou, R.; Moneo, M.; Quiroga, S. Towards adaptation of agriculture to climate change in the Mediterranean. Reg. Environ. Chang. 2011, 11, 159-166. [CrossRef]

45. Forzieri, G.; Cescatti, A.; e Silva, F.B.; Feyen, L. Increasing risk over time of weather-related hazards to the European population: A data-driven prognostic study. Lancet Planet. Health 2017, 1, e200-e208. [CrossRef]

46. Reed, M.S.; Graves, A.; Dandy, N.; Posthumus, H.; Hubacek, K.; Morris, J.; Prell, C.; Quinn, C.H.; Stringer, L.C. Who's in and why? A typology of stakeholder analysis methods for natural resource management. J. Environ. Manag. 2009, 90, 1933-1949. [CrossRef] [PubMed]

47. Hardy, P.Y.; Dray, A.; Cornioley, T.; David, M.; Sabatier, R.; Kernes, E.; Souchère, V. Public policy design: Assessing the potential of new collective Agri-Environmental Schemes in the Marais Poitevin wetland region using a participatory approach. Land Use Policy 2020, 97, 104724. [CrossRef]

48. Marchand, P.; Ratinaud, P. Les Primaires Socialistes Pour L'élection Présidentielle Française (September-October 2011). L'analyse Similitude Appliquée Aux Corpus Textuels 2012, 687-99 Pascal et al._L'analyse De Similitude Appliquee Aux Corpus Textuels.pdf. Available online: http://lexicometrica.univ-paris3.fr/jadt/jadt2012/Communications/Marchand (accessed on 20 September 2021).

49. Lahlou, S. A Method to Extract Social Representations from Linguistic Corpora. Jpn. J. Exp. Soc. Psychol. 1996, 35, 278-291. [CrossRef]

50. APA. Plano de Gestão de Região Hidrográfica-Parte 2: Caracterizção e Diagnóstico. 2016. Available online: https: / apambiente. pt/agua/planos-de-gestao-de-regiao-hidrografica (accessed on 14 February 2019).

51. EDIA. Activities Report, 1st Trimester. 2018. Available online: https://www.edia.pt/wp-content/uploads/2019/05/relatorio_ atividades1trimestre2018.pdf (accessed on 20 June 2019).

52. DGADR. Aproveitamentos Hidroagrícolas-2018. Available online: https://www.dgadr.gov.pt/nec-hidricas-culturas (accessed on 20 February 2019).

53. Monteiro, J.P.; Costa, L.; Rey, F.G.; Olias, M.; Fialho, J.M.R.R.A. Relatório de Compatibilização Quantitativa dos Usos da Água e Identificação de Limitações à sua Qualidade na Sub-Bacia do Baixo. 2018. Available online: https://www.valagua.com/ downloads-tecnicos (accessed on 19 January 2022).

54. Nunes, J.P.; Jacinto, R.; Keizer, J.J. Combined impacts of climate and socio-economic scenarios on irrigation water availability for a dry Mediterranean reservoir. Sci. Total Environ. 2017, 584, 219-233. [CrossRef]

55. Alexandre, C.; Borralho, T.; Durão, A. Avaliação da salinização e sodização em áreas de regadio com dados limitados do solo: Estudo de caso no sul de Portugal. Spanish J. Soil Sci. 2018, 8, 102-120.

56. Chícharo, M.A.; Chícharo, L.; Morais, P. Inter-annual differences of ichthyofauna structure of the Guadiana estuary and adjacent coastal area (SE Portugal/SW Spain): Before and after Alqueva dam construction. Estuar. Coast. Shelf Sci. 2006, 70, 39-51. [CrossRef]

57. Palma, P.; Ledo, L.; Soares, S.; Barbosa, I.R.; Alvarenga, P. Spatial and temporal variability of the water and sediments quality in the alqueva reservoir (Guadiana Basin; Southern Portugal). Sci. Total Environ. 2014, 470, 780-790. [CrossRef]

58. Penha, A.M.; Chambel, A.; Murteira, M.; Morais, M. Influence of different land uses on groundwater quality in southern Portugal. Environ. Earth Sci. 2016, 75, 622. [CrossRef]

59. Santos, F.G.; Dos Gomes, J.C.; Palma, J.; Silveira, A.J. O Impacto Económico Da Agricultura De Regadio De Alqueva. Potenciação Dos Seus Impactes. 14o Congr Da Água -Gestão Dos Recur Hídricos Novos Desafios 2018. Available online: http:/ /www.edia. pt/folder/galeria/ficheiro/240_14CA_98_bf3x8f41g9.pdf (accessed on 25 August 2021).

60. Valverde, P.; Serralheiro, R.; de Carvalho, M.; Maia, R.; Oliveira, B.; Ramos, V. Climate Change Impacts on Irrigated Agriculture in the Guadiana River Basin (Portugal). Agric. Water Manag. 2015, 152, 17-30. [CrossRef]

61. Esgalhado, C.; Guimaraes, M.H. Unveiling contrasting preferred trajectories of local development in southeast Portugal. Land 2020, 9, 87. [CrossRef]

62. Chícharo, L.; Hamadou, R.B.; Amaral, A.; Range, P.; Mateus, C.; Piló, D.; Marques, R.; Morais, P.; Chícharo, M.A. Application and demonstration of the ecohydrology approach for the sustainable functioning of the guadiana estuary (South Portugal). Ecohydrol. Hydrobiol. 2009, 9, 55-71. [CrossRef]

63. Sampath, D.M.R.; Boski, T.; Silva, P.L.; Martins, F.A. Morphological evolution of the Guadiana estuary and intertidal zone in response to projected sea-level rise and sediment supply scenarios. J. Quat. Sci. 2011, 26, 156-170. [CrossRef]

64. García-Tejero, I.F.; Durán-Zuazo, V.H.; Muriel-Fernández, J.L. Towards sustainable irrigated Mediterranean agriculture: Implications for water conservation in semi-arid environments. Water Int. 2014, 39, 635-648. [CrossRef]

65. Silveira, A.; Ferrão, J.; Schmidt Muñoz-Rojas, J.; Pinto-Correia, T.; Guimarães, M.H.; Schmidt, L. The sustainability of agricultural intensification in the early st insights from the olive oil production in Alentejo. In Changing Societies: Legacies and Challenges the Diverse Worlds of Sustainability; Delicado, A., Domingos, N., Sousa de, L., Eds.; Imprensa de Ciências Sociais: Lisbon, Portugal, 2018; pp. 247-275. 
66. Rodríguez-Ortega, T.; Bernués, A.; Olaizola, A.M.; Brown, M.T. Does intensification result in higher efficiency and sustainability? An emergy analysis of Mediterranean sheep-crop farming systems. J. Clean. Prod. 2017, 144, 171-179. [CrossRef]

67. Kuzdas, C.; Wiek, A.; Warner, B.; Vignola, R.; Morataya, R. Integrated and participatory analysis of water governance regimes: The case of the Costa Rican dry tropics. World Dev. 2015, 66, 254-268. [CrossRef]

68. Iglesias, A.; Santillán, D.; Garrote, L. On the Barriers to Adaption to Less Water under Climate Change: Policy Choices in Mediterranean Countries. Water Resour. Manag. 2018, 32, 4819-4832. [CrossRef]

69. Ramos, T.B.; Darouich, H.; Šimůnek, J.; Gonçalves, M.C.; Martins, J.C. Soil salinization in very high-density olive orchards grown in southern Portugal: Current risks and possible trends. Agric. Water Manag. 2019, 217, 265-281. [CrossRef]

70. Woodhouse, P.; Muller, M. Water Governance-An Historical Perspective on Current Debates. World Dev. 2017, 92, $225-241$. [CrossRef]

71. Gupta, J.; Pahl-Wostl, C.; Zondervan, R. “Glocal” water governance: A multi-level challenge in the anthropocene. Curr. Opin. Environ. Sustain. 2013, 5, 573-580. [CrossRef]

72. Guimarães, M.H.E.; Mascarenhas, A.; Sousa, C.; Boski, T.; Dentinho, T.P. The impact of water quality changes on the socioeconomic system of the guadiana estuary: An assessment of management options. Ecol. Soc. 2012, 17, 38. [CrossRef]

73. van Buuren, A.; Klijn, E.H.; Edelenbos, J. Democratic Legitimacy of New Forms of Water Management in the Netherlands. Int. J. Water Resour. Dev. 2012, 28, 629-645. [CrossRef]

74. Hoekstra, A.Y. The global dimension of water governance: Why the river basin approach is no longer sufficient and why cooperative action at global level is needed. Water 2011, 3, 21-46. [CrossRef]

75. Yi, H.; Huang, C.; Chen, T.; Xu, X.; Liu, W. Multilevel environmental governance: Vertical and horizontal influences in local policy networks. Sustainability 2019, 11, 2390. [CrossRef] 